\title{
Biology and Management of Thickhead (Crassocephalum crepidioides) in Ornamental Crop Production ${ }^{1}$
}

\author{
Allison Bechtloff, Shawn Steed, Chris Marble, and Nathan Boyd ${ }^{2}$
}

Species Description: Dicotyledonous plant

Family: Asteraceae

Other Common Names: Redflower ragleaf, ebolo, gbolo, fireweed, hawksbeard velvetplant

Life Span: Summer annual (flowering and fruiting August-December)

Habitat: Occurs in moist, newly disturbed areas from spring to fall. Usually found in full sun in wet areas.

Distribution: Thickhead is native to tropical Africa, but has been widely cultivated in Asia as a medicinal and nutritional herb. It was introduced to the United States and can be found in Florida, Hawaii, and Puerto Rico. In Florida, it has been reported in Escambia, Alachua, Marion, Hernando, Orange, Brevard, Hillsborough, DeSoto, Martin, Lee, Collier, Palm Beach, Broward, and Miami-Dade counties.

Growth Habit: Erect (upright), sparingly branched, herbaceous annual, growing up to 4 feet tall (Figure 1).

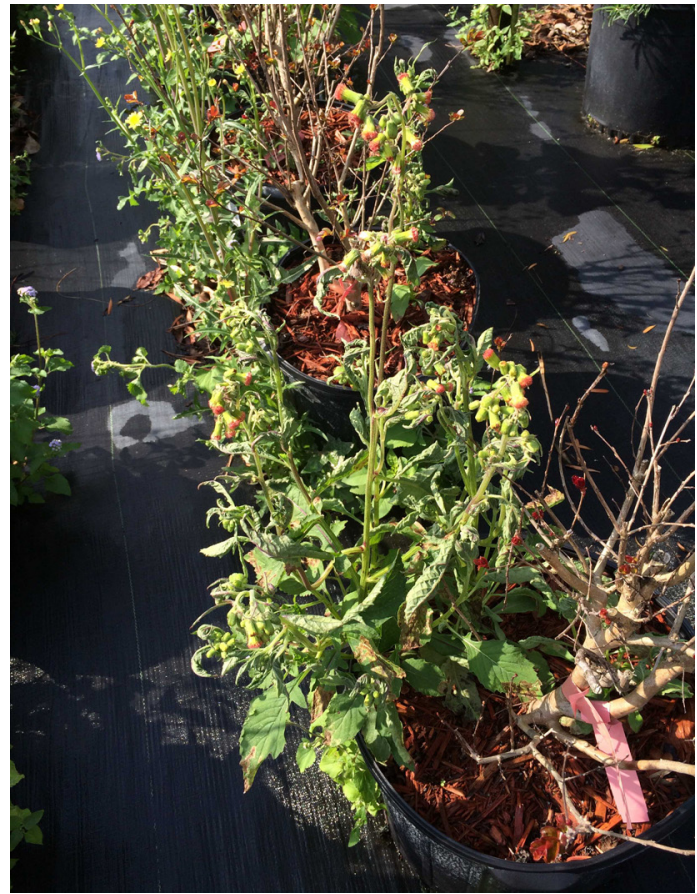

Figure 1. Upright growth habit of thickhead (Crassocephalum crepidioides).

Credits: Chris Marble, UF/IFAS Mid-Florida Research and Education Center

Seedling: Cotyledons are light green with opposite, spatulate (spatula-shaped) leaves with smooth margins. The first true leaves will be light green, elliptical (oval-shaped) with

1. This document is ENH1271, one of a series of the Environmental Horticulture Department, UF/IFAS Extension. Original publication date November 2016. Visit the EDIS website at http://edis.ifas.ufl.edu.

2. Allison Bechtloff, graduate student, Environmental Horticulture Department; Shawn Steed, multi-county environmental horticulture production Extension agent III, UF/IFAS Extension Hillsborough County; Chris Marble, assistant professor, UF/IFAS Mid-Florida Research and Education Center; and Nathan S. Boyd, associate professor, UF/IFAS Gulf Coast REC; UF/IFAS Extension, Gainesville, FL 32611. 
toothed margins growing in a rosette. Veins are slightly red in color (Figures. 2 and 3).

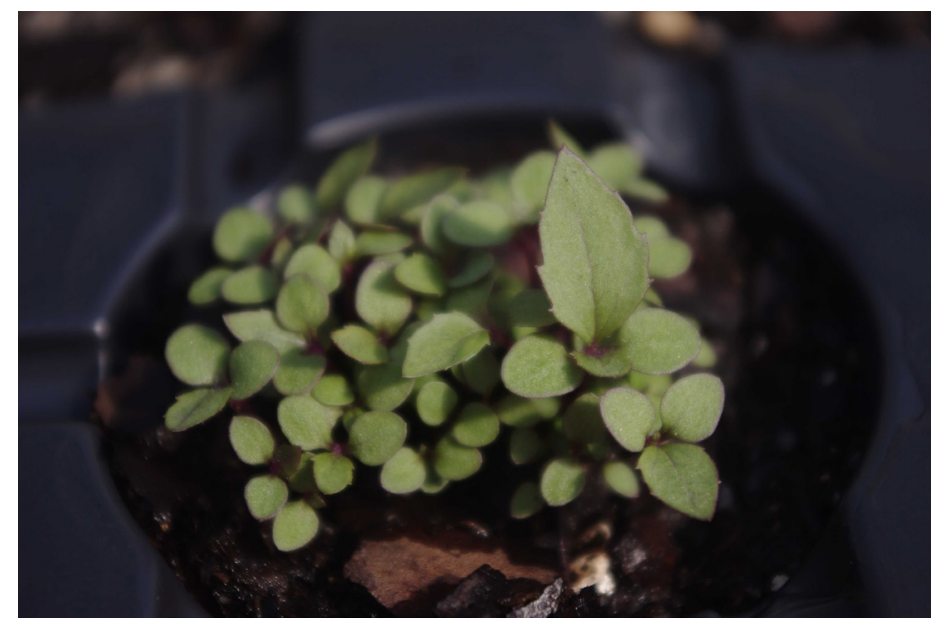

Figure 2. Thickhead cotyledon and first true leaf.

Credits: Annette Chandler, UF/IFAS Mid-Florida Research and Education Center

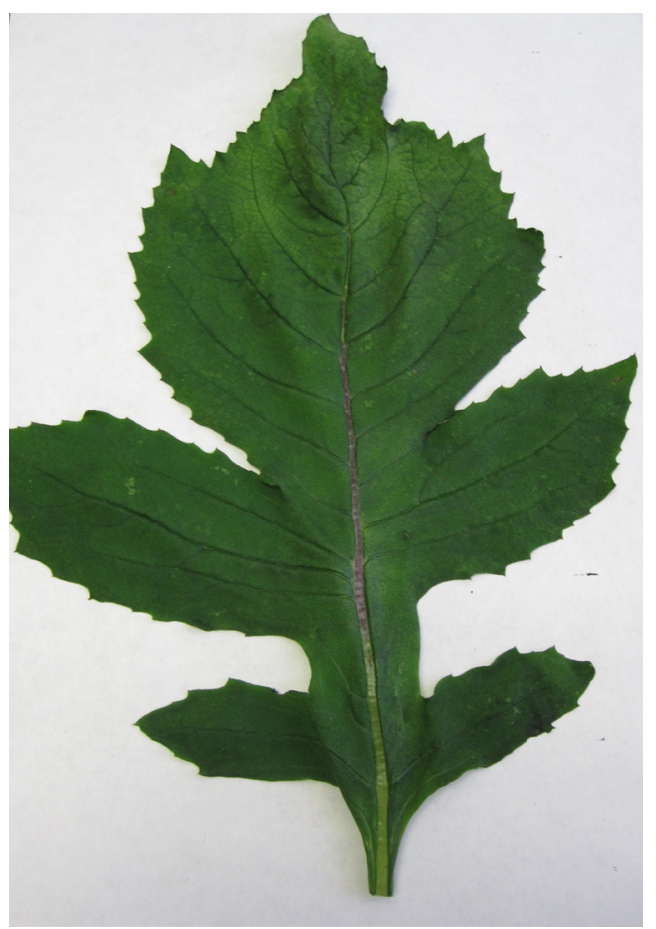

Figure 3. Mature thickhead leaf.

Credits: Shawn Steed, UF/IFAS Extension Hillsborough County

Shoot: Stems are round and ribbed with short, thick hairs near the apical portion of the plant on the stem and branches. The lower plant is glabrous (smooth/without hairs). Newer leaves are alternate, green, elliptical (ovalshaped), 1.5-8 in long, and 0.4-4 in wide, with irregularly toothed margins. Leaves will be slightly lobed near the apex, with only a small pair of lobes near the base of the leaf, and deeply lobed in older growth (Figure 3).

Roots: Fibrous

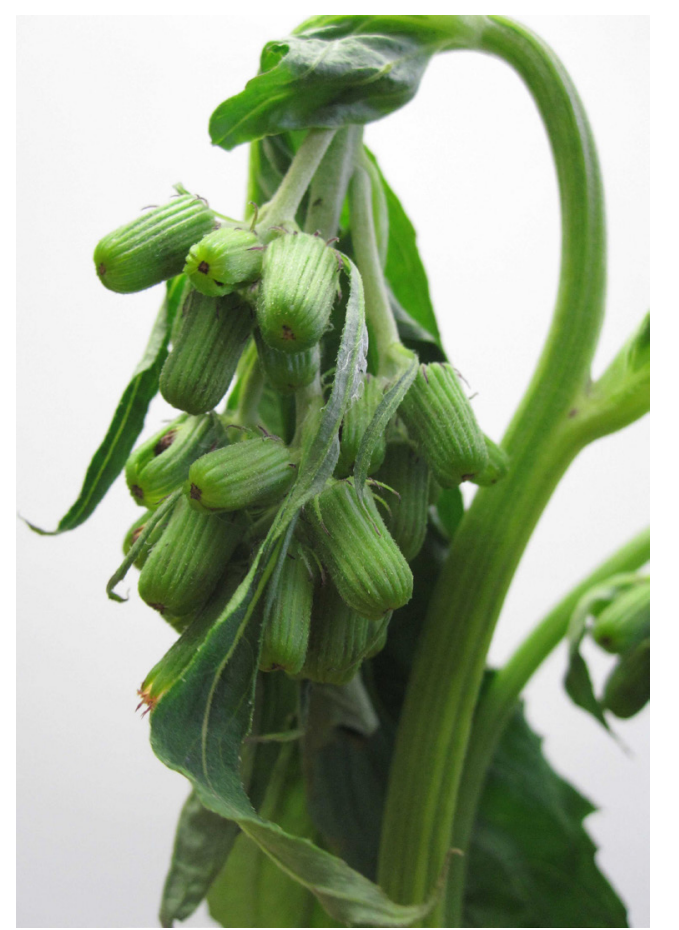

Figure 4. Thickhead stem and typical drooping flowering stalk. Credits: Shawn Steed, UF/IFAS Extension Hillsborough County Inflorescence: From summer to fall, clusters of reddishorange to reddish-pink flower heads develop at the apex of the plant. Flowers are cylindrical, about $10 \mathrm{~mm}$ long and 4 $\mathrm{mm}$ wide. Flower heads droop downward as if from water stress during flowering (Figure 4).

Fruit and Seeds: Each flower head produces multiple achenes about $2 \mathrm{~mm}$ long that are dark-reddish brown and attached to silky hairs (pappus) that are about 9-10 $\mathrm{mm}$ long. The hairs allow the achenes to be wind dispersed.

Similar Species: American Burnweed (Erechtites hieracifolia) does not have leaves as thick or deeply veined as thickhead. Brazilian or Tropical Burnweed (Erechtites valerianaefolia) has more flower heads than thickhead, and the flower heads are mauve colored. Emilia (Emilia sonchifolia var. javanica) has similar features, but the flower heads do not droop and are bright pink; the leaves are more hairy than thickhead. Emilia has only been introduced to Hawaii in the United States at this time. Other Crassocephalum species also have similar features but need to be examined to be certain.

\section{Plant Biology}

Thickhead generally grows from spring to fall in north and central Florida and year-round in south Florida. It germinates over a wide range of $\mathrm{pH}$, salt, and temperature conditions and preferentially when the seed is on or slightly below the media surface (Nakamura and Hossain 2009, Chen et al. 2009). Thickhead germination is higher in 
warm, saturated, or flooded conditions; and, as a result, it typically occurs in poorly drained fields, irrigated areas, roadsides, or during periods of heavy rainfall (Nakamura and Hossain 2009). Each flower can produce 91-150 seeds, producing up to 750-1,150 seeds per plant (Sakpere et al. 2013). Persistence in fields and container production is due to the thousands of seeds produced per plant over the course of a growing season (Nakamura and Hossain 2009). Seeds can germinate anywhere from $50^{\circ} \mathrm{F}-86^{\circ} \mathrm{F}$ (optimal $\left.=59^{\circ}-68^{\circ}\right)$, at a pH of 2-12 (optimal 4-10). Seeds have a $90 \%$ germination rate from mature (wind dispersed) seeds at 2-12 days after making contact with media (highest germination rate is day 6) (Chen et al. 2009). Flowers can set seed in 10-12 days from initial flower opening (Sakpere et al. 2013). Thickhead grows aggressively in containers and can outcompete nursery crops for water, nutrients, and light. Thickhead is typically found in shadehouses and shaded areas of nursery production.

\section{Management \\ Physical and Cultural}

Hand weeding when plants are small is the best physical preventative measure. Increasing light levels and reducing application of irrigation water can help prevent germination. Using a bark mulch that prevents seed-to-soil contact might prevent seed germination. If thickhead plants escape control by various methods, the plant should be prevented from flowering in the nursery or liner bank. If flower stalks are evident in a localized area and seed dispersal is imminent, as a last ditch effort some growers have cut the stalks with machetes or hedge trimmers to prevent wind dispersal of the seeds. Seed dispersal by wind will cause a wide-spread problem throughout the nursery. Keeping field margins and border areas clean will help prevent seed dispersals. All liners and bought-in plants should be isolated and monitored for thickhead seedlings before being dispersed into the nursery.

\section{Chemical Control}

\section{PREEMERGENCE}

Very few preemergence herbicides labeled for use in nursery production or landscapes contain recommendations for control of thickhead. One herbicide that lists thickhead as a controlled species is flumioxazin, which is sold as Broadstar $^{\mathrm{TM}}$ and SureGuard ${ }^{\circledR}$. Broadstar ${ }^{\mathrm{TM}}$ is a granular formulation of flumioxazin and can be applied to containergrown ornamentals and to established plants in landscapes. SureGuard ${ }^{\circledR}$ is a dry flowable sprayable formulation and is only labeled as a directed application around most ornamentals. Other herbicides that provide suppression or control of thickhead include indaziflam (Marengo ${ }^{\circledR}$ or Specticle ${ }^{\circledR}$ ) and products containing dimethenamid-p (FreeHand ${ }^{\circledR}$ and Tower $^{\circledR}$ ). Other preemergence herbicides are listed in Table 1. Additional herbicide recommendations are available at https://www.cals.ncsu.edu/plantbiology/ ncsc/containerWeeds/Crassocephalum_crepidioides.htm.

\section{POSTEMERGENCE}

There are many different postemergent herbicides that are effective for thickhead control but all should be applied as a directed application. Effective active ingredients would include glyphosate (RoundUp ${ }^{\circledR}$ and many other trade names), glufosinate (Finale ${ }^{\circledR}$ ), diquat (Reward ${ }^{\circledR}$ ), pelargonic acid (Scythe ${ }^{\circledR}$ ), among several others. Both systemic and contact herbicides typically provide effective control, but thorough coverage is needed for contact herbicides such as diquat or pelargonic acid. Postemergent herbicides are most effective when the weeds are small and actively growingthis is especially true for contact action herbicides. Always consult the manufacturer's label and follow all precautions when applying herbicides.

\section{References}

Chen, Guo Qi, Shio Liang Guo, and Qiu Sheng Huang. 2009. "Invasiveness evaluation of fireweed (Crassocephalum crepidioides) based on its seed germination features." Weed Bio. And Mgmt. 9:123-128.

Mallory-Smith, C.A. and E.J. Retzinger Jr. 2003. "Revised Classification of Herbicides by Site of Action for Weed Resistance Management Strategies." Weed Technology, 17(3):605-619.

Nakamura, Ichiro and Mohammad Amzad Hossain. 2009.

"Factors Affecting the Seed Germination and Seedling Emergence of Redflower Ragleaf (Crassocephalum crepidioides)." Weed Bio. And Mgmt. 9:315-322.

Sakpere, A.M.A., O. Adedeji, and A.T. Folashade. 2013. "Flowering, Post-Pollination Development, and Propagation of Ebolo (Crassocephalum crepidioides (Benth.) S. Moore) in Ile-Ife, Nigeria." Journal of Science and Tech. 33:37-49. 
Table 1. Preemergence herbicides labeled for use in ornamental plant production and landscapes to control thickhead.

\begin{tabular}{|c|c|c|c|c|c|c|c|}
\hline $\begin{array}{l}\text { Common name (active } \\
\text { ingredient) }\end{array}$ & $\begin{array}{l}\text { Example trade name } \\
\text { and formulation }\end{array}$ & $\begin{array}{c}\text { WSSA } \\
\text { Herbicide } \\
\text { Group }\end{array}$ & Efficacy $^{2}$ & $\begin{array}{l}\text { Container } \\
\text { production }\end{array}$ & $\begin{array}{l}\text { Field } \\
\text { production }\end{array}$ & $\begin{array}{c}\text { Greenhouse } \\
\text { or fully- } \\
\text { enclosed } \\
\text { structures }\end{array}$ & Landscape \\
\hline prodiamine & Barricade ${ }^{\circledR} 4 \mathrm{FL}, 65$ WG & 3 & $\mathrm{~S}$ & YES & YES & NO & YES \\
\hline \multirow[t]{2}{*}{ flumioxazin } & Broadstar $^{\mathrm{TM}} 0.25 \mathrm{G}$ & \multirow[t]{2}{*}{14} & \multirow[t]{2}{*}{$\mathrm{S}-\mathrm{C}$} & YES & YES & NO & YES \\
\hline & SureGuard ${ }^{\circledR} 51$ WDG & & & $\mathrm{YES}^{3}$ & $\mathrm{YES}^{3}$ & NO & $\mathrm{YES}^{4}$ \\
\hline oxadiazon & Ronstar ${ }^{\circledR} 2 \mathrm{G}$ & 14 & $\mathrm{~S}$ & YES & YES & NO & YES \\
\hline dimethenamid-p & Tower ${ }^{\circledR} 6 \mathrm{EC}$ & 15 & $\mathrm{C}$ & YES & YES & NO & YES \\
\hline isoxaben & Gallery ${ }^{\circledR} 75 \mathrm{DF}, 4.16 \mathrm{SC}$ & 21 & $\mathrm{C}$ & YES & YES & NO & YES \\
\hline \multirow[t]{4}{*}{ indaziflam } & Specticle ${ }^{\circledR} 0.622$ FLO & \multirow[t]{4}{*}{29} & \multirow[t]{4}{*}{$\mathrm{S}-\mathrm{C}$} & NO & NO & NO & YES \\
\hline & Specticle ${ }^{\circledR} 0.0224 G$ & & & NO & NO & NO & YES \\
\hline & Marengo ${ }^{\circledR} 0.622 S C$ & & & $\mathrm{NO}^{5}$ & YES & $\mathrm{YES}^{6}$ & NO \\
\hline & Marengo $^{\circledR} 0.0224 \mathrm{G}$ & & & YES & YES & NO & NO \\
\hline $\begin{array}{l}\text { pendimethalin }+ \\
\text { dimethenamid-p }\end{array}$ & FreeHand ${ }^{\circledR} 1.75 G$ & $3+15$ & $\mathrm{~S}-\mathrm{C}$ & YES & YES & NO & YES \\
\hline trifluralin + isoxaben & Snapshot ${ }^{\circledR} 2.5 \mathrm{TG}$ & $3+21$ & $\mathrm{~S}$ & YES & YES & NO & YES \\
\hline prodiamine + isoxaben & Gemini $^{T M} 3.7 \mathrm{SC}$ & $3+21$ & $\mathrm{C}$ & YES & YES & NO & NO \\
\hline oxyfluorfen + oryzalin & Rout $^{\circledR} 3 G$ & $14+3$ & C & YES & YES & NO & YES \\
\hline oxyfluorfen + pendimethalin & $\mathrm{OH} 2{ }^{\circledR} 3 \mathrm{G}$ & $14+3$ & C & YES & YES & NO & YES \\
\hline \multicolumn{8}{|c|}{$\begin{array}{l}{ }^{1} \text { Herbicide groups are based according to primary sites of action and can be used to select herbicides that have differing sites of action } \\
\text { (Mallory-Smith and Retzinger 2003) so as to minimize the potential for the development of herbicide resistant weeds. }\end{array}$} \\
\hline \multicolumn{8}{|c|}{$\begin{array}{l}{ }^{3} \text { Can only be used in selected conifer and deciduous tree species. Check manufacturer's label for a complete list of species and recommended } \\
\text { application methods. }\end{array}$} \\
\hline \multicolumn{8}{|c|}{${ }^{4}$ Can be applied as a directed application around established woody landscape ornamentals. } \\
\hline \multicolumn{8}{|c|}{$\begin{array}{l}{ }^{5} \text { Marengo } 0.622 \mathrm{SC} \text { can be used in pot-in-pot container ornamentals as a directed application only. Specticle }{ }^{\mathrm{TM}} \text { is the same active ingredient } \\
\text { but labeled for use in landscapes. }\end{array}$} \\
\hline \multicolumn{8}{|c|}{${ }^{6}$ Labeled for use on greenhouse floors prior to plant production. Plants can be placed back inside greenhouse 24 hrs after application. } \\
\hline
\end{tabular}

